\title{
Investigation and analysis of color pragmatics in Beyghami DarabNameh
}

\section{Investigación y análisis de la pragmática del color en Beyghami DarabNameh}

\author{
Susan Bigleri Delavii \\ $\mathrm{PhD}$ student in Persian Language and Literature, Islamic Azad University, Mashhad \\ Branch, Iran \\ Reza Ashrafzadeh \\ Department of Persian Language and Literature, Islamic Azad University, Mashhad \\ Branch, Iran \\ Javad Mehraban Ghezelhesar \\ Department of Persian Language and Literature, Islamic Azad University, Mashhad \\ Branch, Iran
}

*Correspondence

Email: RezaAshrafzadeh@gmail.com
Cite as:

Delavii, S., Ashrafzadeh, R., \& Ghezelhesar, J (2021). Investigation and analysis of color pragmatics in Beyghami DarabNameh. Propósitos y Representaciones, 9 (SPE1), e870. Doi: http://dx.doi.org/10.20511/pyr2021.v9nSPE1.870 


\section{Summary}

In the present article, the function of colors in Beyghami DarabNameh has been investigated by descriptive-analytical method. The most frequent colors in this prose work are black and red; the main reason for this frequency is the epic content and the occurrence of successive wars. A common function seen in all colors is the descriptive aspect. In addition, the description of the biological and psychological conditions of the characters, the induction of inner emotions and objectification of abstract concepts has been done with the help of colors. In general, the colors used in DarabNameh are non-symbolic, explicit and direct, and lack multiple layers of meaning, which indicates the realistic and objectivist attitude of the author. The most important weakness of Beyghami in the field of storytelling, which is revealed by analyzing the pragmatics of colors, is the imbalance in its application in the narrative process.

Keywords: Beyghami, DarabNameh, color, black, red, yellow, green.

\section{Resumen}

En el presente artículo, la función de los colores en Beyghami DarabNameh ha sido investigada por el método descriptivo-analítico. Los colores más frecuentes en esta obra en prosa son el negro y el rojo; la principal razón de esta frecuencia es el contenido épico y la ocurrencia de guerras sucesivas. Una función común que se ve en todos los colores es el aspecto descriptivo. Además, la descripción de las condiciones biológicas y psicológicas de los personajes, la inducción de emociones internas y la objetivación de conceptos abstractos se ha realizado con la ayuda de colores. En general, los colores utilizados en DarabNameh son no simbólicos, explícitos y directos, y carecen de múltiples capas de significado, lo que indica la actitud realista y objetivista del autor. La debilidad más importante de Beyghami en el campo de la narración, que se revela al analizar la pragmática de los colores, es el desequilibrio en su aplicación en el proceso narrativo.

Palabras clave: Beyghami, DarabNameh, color, negro, rojo, amarillo, verde.

\section{Introduction}

Undoubtedly, colors play an important role in improving the quality of human life and as a spice of creation; they are a valuable element in presenting various concepts and evoking a human aesthetic sense. Colors represent a variety of concepts, and part of each person's inner personality and way of thinking and feeling can be understood by analyzing his or her favorite colors. Therefore, colors are not neutral and induce different and sometimes contradictory meanings. Depending on factors such as climate, customs, ancient beliefs, etc., the semantic load of colors may be different in different cultures. In the contemporary era, the issue of the importance of colors in various sciences, including psychology, has been seriously discussed and pursued. Prominent scientific personalities have made new discoveries about the function of colors in a person's personal and social life by turning to theoretical and field research. Max Lüscher believes that the effect of color on the human psyche is to the extent that it not only helps to read the minds of writers, but also has revolutionized many other sciences. (Losher, 1389: p. 29) Psychologists carefully recognize the hidden layers of personality in the use of colors.(Sun and Sun, 1378: p. 58) Paying attention to colors and addressing the role of this element in human life, has been prominent since ancient times. One of the areas of expression of various colors and visual concepts is the written literary works of nations. The element of color is reflected in the culture of all people, despite more or less differences. Many romances, epic, mystical, fictional, etc. works have a long history of familiarity with color, and the authors have used this element to convey their meaning. 


\section{Problem statement and the importance of research}

Beyghami DarabNameh is a prose work that describes the life and battles of Darab, Shah Kiani and his fictional son, Firuz Shah. This work has survived from the ninth century AH and the author has been clearly influenced by pre-Islamic stories in representing the narrations. DarabNameh is one of the folk tales published in three volumes. The first two volumes were published by the book translation and publishing company in 1339, thanks to the efforts of Zabihullah Safa. The third volume, entitled Firooz Shahnameh, was published by Cheshmeh Publishing in Tehran in 2009 by Iraj Afshar and Mehran Afshari. This work can be studied from various aspects and is of special importance in the field of Persian literature. Beyghami has used various tricks in narrating the narratives and descriptions of the heroism of Firooz and other Iranian heroes, including the purposeful use of the element of color. Relying on the communication capacities of colors, the author has taken an important step in facilitating the process of semantics by the audience and their relative persuasion. Since colors are an important element in the scientific and methodical reading and analysis of literary texts and the recognition of fictional characters, the analysis of literary works with an approach to this phenomenon provides the audience with new aspects of the author's art and the overlooked capabilities of the work. Therefore, in the present article, relying on the descriptive method and content analysis technique, the pragmatics contexts of black, red, yellow and green in this work have been investigated to answer the following questions:

A. What are the most frequent colors in Beyghami DarabNameh?

B. What are the main functions of colors by Beyghami?

C. What aspects of fictional characters are revealed through the use of colors?

\section{Research background}

So far, no study has mentioned the function of colors in Beyghami DarabNameh, which adds to the innovative aspects of the present article. However, several studies have addressed parts of Beyghami's storytelling art and the quality of his work. Jafarpour and Alavi Moghadam (2013), in an article, have examined the theme of Ayari and the young man and its didactic-inductive teachings in Persian prose epics such as DarabNameh. From the authors' point of view, striving to gain a name and avoid stigma, truth in word and deed, adherence to covenants and oaths, secrecy and trustworthiness, decency in behavior, courage, generosity and kindness, honoring guests and respecting fellow travelers, people Friendship and diligence are the most important moral and educational advices that have been considered in the mentioned works. Sarfi and Rahimi Sadegh (2016), in an article, have examined the type of narration of DarabNameh and have come to the conclusion that according to Todorov, this work is in the line of mythical narratives. In DarabNameh, the narrator's attention to the description of appearances and tangible things such as the hero's clothing and their war uniforms, the method of struggle, windfalls, etc., diminishes the importance of penetrating into the characters and exploring their thoughts and feelings. Give. What distinguishes the present article from the mentioned researches is the method of colors and the quality of function of this element in DarabNameh, from a methodical and scientific point of view.

\section{Theoretical framework of research}

Max Luscher is a psychotherapist and professor of psychology at the University of Bessel. He has made many innovations in the field of psychology, one of which is the invention of a test called the Luscher color test. This test is a tool for measuring the psychological state based on colors. "Luscher first proved in 1940 that colors not only have the ability to convey messages, feelings and emotions, but also have energy healing, and almost everyone who deals with color in some way is more or less aware of its effects." (Fillmar, 1997: p. 24) He found that different colors create different emotions. Sometime later, "by reversing this theory, he claimed that different 
colors could represent different behaviors and moods, and as a result, each person's favorite color reflects his mental state and the quality of his action towards the world around him." (Sun and Sun, 1999: p. 49) Luscher's views are explained in the book Psychology of Colors. In his view, there are four primary colors (red, blue, green, and yellow) and four secondary colors (black, gray, purple, and brown) in nature. In the present article, according to the color frequency in DarabNameh, three main colors (red, green and yellow) and one sub-color (black) have been studied and analyzed.

\section{Backgrounds of color pragmatics in Beyghami DarabNameh}

In Beyghami DarabNameh, colors are used to better depict epic scenes. Therefore, the author has not deviated from the intellectual policy of the book and has not dealt much with non-epic issues. Sometimes in this work, a color finds a paradoxical function and the author uses happy and bright colors to explain negative concepts. In this section, the main functions of black, red, yellow and green colors are examined.

\section{Black}

Black was the most common color in DarabNameh. In all the stories, the author has dramatically used the color black and its accessories, such as darkness, night, smoke, etc., and has made it easy for the audience to communicate with the produced text. The pragmatics of this color in DarabNameh is more varied than other colors. This indicates that the author had a particular focus on black communication capabilities. In total, four functions are defined for black in the work: inducing the negative dimensions of war to the audience, representing the unpleasant aspects of illness and death, explaining the timing of events, describing and explaining the negative inner emotions. These cases will be discussed below.

\section{inducing the negative dimensions of war to the audience}

Lusher believes that black represents emptiness and black and is used in contrast to white.(Lusher, 2010: p. 97) The author of DarabNameh has an epic approach and has described the heroism of Darab and Firuz Shah using epic elements. One of the main functions of this color in DarabNameh is to create an unpleasant feeling towards war. From Beyghami's point of view, just as night's light fades and is replaced by destruction, so does war, and it destroys the peace of the people and the lands and by increasing the sense of despair in the war victims, it institutionalizes emptiness in the fabric of their existence. By using this color accurately, Beyghami conveys such a feeling to his audience and indirectly condemns the ominous phenomenon of war. For example, he writes in a part of the story: "In the middle of that night, the song of a military cousin from the Iranian army reached the eighth heaven."The army woke up, wondering if the Yemenis had brought an ambush."(Beyghami, 1960, vol. 1: p. 335) What are derived from this phrase is the unpleasant feelings that arise for individuals in any war. In another part of the story, the Zangian and Darfash corps and their type of war formation are described. By emphasizing the color black and repeating it several times, Beyghami has announced the beginning of a military confrontation that will lead to destruction: "From the heart of thirty sciences, the sign of thirty thousand bloodthirsty men was found, The sentence of the black sciences of the body, one is the great science of the black part, and the wind is wrapped in that part, at the foot of that living black science there is a pillar, it is very tall. "King Darab did not know who they were and where they came from." (Ibid: p. 337) 1-2. Representation of the unpleasant aspects of illness and death

Beyghami has used the power of black media to explain illness and death. Man has constantly turned away from these two phenomena and was afraid of getting them. Therefore, it has shown its negative view of it with the bitterest color, namely black. Luscher also mentions this in his theory. In his view, "black represents the absolute boundary beyond which life stops 
and therefore represents the thought of emptiness and destruction."(Luscher, 2010: p. 97)Therefore, when Beyghami speaks of sick and dying characters, it uses black color and its accessories to better convey the unpleasant atmosphere of the narrative to the audience and increase the quality of his communication with the text and the physical and mental condition of the characters. In one part of the story, Farrokhzad, a descendant of Rostam Dastan, is fighting a wicked robbery. He has shown his resilience against this demonic enemy in full military form, but in an instant, he is subdued by his power and the enemy's sword falls on his head.

This blow blurs the world before his eyes and he becomes helpless and unconscious: "Half a dark man was fighting over a dark head when the thief gave birth to that wound on Farrokh. Oh, Farrokhzad died, but the accursed one who was beaten died. "The world became black and dark in Farrokhzad's eyes, but he put his foot firmly on the pedal and threw his hands in the compound mane and became helpless."(Beyghami, 1960, vol. 1: p. 47)In another story, Firuz Shah goes to sea with Qader Shah and others. After a while, they reach an island with a strange climate.Upon arriving on the island, the ship's inhabitants undergo a physical transformation and find themselves in unfavorable conditions. Beyghami described the situation of Firuz Shah and his companions well and used black to better explain what he meant: "Bile fell on them and their eyes turned black. Some vomited and their heads turned and their hearts revolted and their minds disappeared. "Everyone left, some became unconscious out of fear."(Ibid: p. 75)

\section{Explain the time of events}

One of the functions of black seen in DarabNameh is to specify the timing of certain events. With this literary trick, the author has prevented the audience from resorting to speculation and has given an accurate picture of the time of the events. This method has a positive effect on the focus of the audience. In one part of the story, Farrokhzad comes to Firooz Shah with all his military tools and expresses his loyalty to him. The author mentions the time of Farrokhzad's departure and his joining Firuz Shah at night, which can be important from a military and security point of view: "So Farrokhzad straightened the furniture. When night came, that night was in the service of Firuz Shah ... because it was midnight, the two young men got on board."Firuz Shah, with tears in his eyes and a sad heart, was forced to follow his heart."(Ibid: p. 25).

Another story is related to the military confrontation between the Cairo Corps and King Khalid, which eventually led to the opening of the gate of King Khalid's castle. Withdrawal from the battle at night is the subject of the author: "That night both corps waited, they opened the castle door on the first day."King Khalid came out of the fort with a large army and lined up in front of the Cairo army."(Ibid: p. 36) a review of this function of the color black in DarabNameh shows that many combat tactics were used, including ambush at night. In one of the stories, we read that Piroozh Zangi, in a surprise, knocks the Yemeni army to the ground and causes serious damage to its body: "The Yemeni army landed at the foot of the mountain until nightfall. "Because he died at midnight, Piroozh Zangi with twenty thousand men came out of the ambush and fell on that sleeping army."(Ibid: p. 86)

\section{Description}

In epic stories, description is one of the most important tools for representing the battles of hostile forces as well as human relations. In DarabNameh, this literary element has been used many times and the vast majority of stories have been narrated mainly through description. The color black has helped Beyghami describe the characters and scenes and added to the consistency of his narrative style. He describes a girl who is unparalleled in beauty and Firuz Shah is heartbroken to see her. What makes this girl stand out in Firooz's eyes is her physical features such as black hair and curly curls: "Suddenly, the face of a girl was found in front of Firuz Shah, whose fragrant pomegranate helped the animal to drink water and Narges, half asleep, was tired of the bow of 
the eyebrows of the souls with sorrow, and she opened the navel of pure musk from the black veil, and sometimes she stole the ball of Simin Zankhodan from the polo of the sand."And from the shadow of its radiance, a violet face has been found on Golnar. "(Ibid: p. 25) the description in DarabNameh is not limited to romantic and lyrical issues, and the main function of this literary tool is to explain military and epic issues. In order to describe the battle scene, Beyghami spoke of the night of Digori, in which the battle took place and continued until near morning and sunrise. The contrast between light and darkness in this descriptive text draws attention: "In the middle of the night, the two armies were fighting and making tools of war until the night of Dijur came and the sun of Jamshid rose and the world became enlightened."(Ibid: p. 106) also, a detailed description of the time and manner of the troops' movement at night is provided: "Because half past night has passed and the world has become black and dark like the love of the beloved, "Shah Sarwar decided to march and Khatir rode with sixty thousand Egyptian men with spears and came to Shah Sarvar."(Ibid: p. 483).

\section{Explaining negative inner emotionsIn the psychology of colors}

"black is the color of sorrow, it is the color of sorrow, black is used in mourning for this, as a symbol, it always maintains sorrow within man." (Farzan, 1375: p. 45)This color is used in this sense in most cultures. In DarabNameh, black is used to indicate the inner characteristics of people. In this way, the audience becomes aware of what is going on inside the characters and is hidden from their eyes due to their invisibility and by understanding the moods of the people at that particular moment; there is no disturbance in the process of his connection with the structure and depth of the narrative. Firoozshah is far from his home and country. He is not in a good mood and can withstand the pressure. In such a situation, suddenly night comes and darkness pervades the whole world and light disappears. Perhaps this illustration can be considered as an allegory to explain Firooz's emotions. He is saddened by the distance from his family and feels frustrated. Happiness has disappeared from his heart and sorrow has invaded his heart and soul. The intersection of night and darkness with the spirits of Firuz Shah has been very effective in giving objectivity to his inner feeling: You said that the smoky oh of the lovers of the space of the universe has closed its head and blackened the time like the letter of the rebels on the Day of Judgment. "The air at the parting of the sun is covered with the color of the sun, and the shadows of the day are hidden in the nests of darkness."(Beyghami, 1960, vol. 1: p. 54).

With the start of the war, the fear of being killed and defeated among all soldiers comes to life. They are afraid of the inevitable and unpredictable future that lies ahead. Beyghami, who has realized this feeling well, tries to make it objective and tangible by using the capabilities of black color. Lighting a torch and fire in the middle of the night is a way to deal with this inner fear and stay safe from the enemy. Beyghami has succeeded in representing the inner emotions of soldiers and warriors by creating a contrast between black and white: "The IRGC started the war and took the lead from both IRGCs. "On that night when the world was black and dark, they lit a hundred thousand lights and torches to reduce their fear."(Ibid: p. 106).

\section{Red}

Red after black has the most reflection in DarabNameh. The reason for this frequency is the many battles and hand-to-hand battles described in the work. Firuz Shah and his other companions, including Cairo Shah, set foot in different lands, faced new dangers and had to fight to take care of themselves. Hence, scenes of bloodshed and murder that are somehow associated with red can be seen in DarabNameh. From the point of view of historical psychology, this color is "rooted in the words life and blood."(Fillmar, 1997: p. 35) and is often used to describe violent scenes. In sum, Beyghami used red to "express violence, conflict, and resentment," to "describe the physical condition and suffering of body and soul," and to "describe." 


\section{Expressing violence, conflict and resentment}

The color red is vivid and at the same time energetic and determined, and almost everywhere means power (Riofray, 1992: p. 97) and is a sign of "anger, nervousness and revenge."(Ayatollah, 2002: p. 118)For this reason, in most of the wars we have witnessed in the past, red has been used as the symbol and color of the flag. "Red speeds up the pulse, raises blood pressure and increases respiration."(Luscher, 2010: p. 86)Seeing this color, the troops were encouraged to fight and showed more effort to win the battle. "Red is symbolically like the blood shed during a victory."(Ibid: p. 87)

In DarabNameh, a scene is depicted where Firuz Shah is lurking in a cave and waiting for the arrival of a vigorous and powerful demon called magic. He hides behind a huge rock and the demon arrives and passes by the rock without noticing the presence of an alien. Firoozshah takes full advantage of this opportunity and cuts the neck of the demon with a severe blow. The author does not suffice in his description to the same extent and informs of the flood of blood in the hiding place of the demon in order to add to the believable dimensions of the described scene and the violence and conflict that ensued. The use of the phrase "a fountain of blood flowed" is said precisely in order to achieve this goal:"Firoozshah was surprised when he looked at Drao. Two eyes, like two bloody bald spots, came out of arrogance until Firuz Shah died. He did not see Firuz Shah. "It's time," said the prince. He came behind him with a razor and made a terrible scream. The magic looked back to see who it was.Prince Firuz Shah struck the buffalo on the neck with such a razor that it cut off its head. "A stream of blood flowed and fell to the ground."(Beyghami, 1960, vol. 1: p. 231).

In the second volume of the book, the scene of struggle and hatred of two rivals, namely Shamut and Tarom, is recounted. In a surprise, Shamut hits his opponent in the thigh and breaks his leg and blood spreads everywhere. Shamut, who sees Tarom's weakness, kills him by landing another blow. The color red has been very effective in inciting military violence between the two heroes. This is how the audience sees themselves in that scene and the story becomes more objective for them: "Suddenly, the brave Shamut came and stabbed Tarom in the thigh, which opened like a fish's mouth and blood gushed out "Turn the ink on Annan to hit another beat and finish Tarom's work."(Ibid., Vol. 2: p. 45).

\section{Description of the physical condition and suffering of body and soul}

The color red covers the physical and physiological aspects of a person and indicates vital force, nervous and glandular activity. (Luscher, 2010: p. 87) In other words, red, unlike many colors, reveals the external and internal characteristics of a person and his mental and physical condition is understood according to this color. "Physical and nervous fatigue, heart disorders and loss of physical strength often occur with a rejection of red."(Ibid: p. 87).

In DarabNameh, this aspect of red has been mentioned many times. In many cases, the author (narrator) has facilitated the narrative process by mentioning the color red and has expanded the audience's understanding. This means that sometimes, instead of referring directly to the unhappy state of the characters, he has used the color red in such a way that the audience notices their unfavorable physical or mental condition. But sometimes, he refers directly to the injury or illness of the characters and uses red as a complement to his description. In a part of the story, we read that Farrokhzad suffers a head injury and loses consciousness in a battle with a rogue thief. His horse takes him to a desert where a man lives alone. Seeing Farrokhzad, the man brought him home and laid him on the felt and applied ointment to his wound to heal him.By explaining the quality of Farrokhzad's wounds and the blood that had flowed from him, Beyghami shared the main cause of his weakness and anesthesia with the audience. In other words, in this 
way, the author explicitly states the cause and effect and reduces the ambiguities of the audience. "Put Farrokhzad to sleep on that felt and look at his wound."Because the fish's mouth was open and a lot of blood was lost. "Farrokhzad fell unconscious and injured. Golban now took milk from the sheep and washed the wound on Farrokhzad's head with hot milk."(Beyghami, 1960, vol. 1: pp. 52-51).

another part of the story, Shah Salim launched a campaign to find his master's top shooter. Farrokhzad, who survived a head injury and his physical condition had somewhat improved, took part in the trial. The archer prepared the bow at the king's command. It was so hard that the archer's face turned red. Beyghami seeks to insinuate and explain that although it was difficult to prepare the bow for the archer, but Farrokhzad took it in his entire hands without changing the color of his face by describing his archer face and physical weakness, Beyghami has confirmed Farrokhzad's strength: "King Salim ordered him to draw a bow first. The archer grabbed the bow and pulled the bow as hard as he could. Sweaty and red, he gave birth to Farrokh and said: O my king! "I have turned this bow into the phrase of the Levant and the arabs, no one has drawn this bow of mine."(Ibid: p. 65)

The following text recounts the conflict between the two characters (Ayar Chaos and Jundaleh). Jundle's injury and bleeding from his limbs, his unfavorable physical condition and the end of resentment are well shown: "The riot of the carnage was killing Jundala. Jundala was astonished and looked in all directions. "Then he drew his dagger and wounded his limbs with the dagger, and blood flowed from his limbs." (Ibid., Vol. 2: pp. 410-409)

\section{Description}

Red is not only used to refer to negative issues, but the potential of this color can be used to represent positive issues. For example, the positive function of this color is seen to describe the horse that is to be given as an offering to Darab Shah. It seems that the rosy horses (red) in the past had a special prestige with the kings and whenever they received such an offer, they provided the necessary grounds for the satisfaction of the offeror. Nik Akhtar and King Fidos consult with each other to extend their intentions to Darab Shah and conclude that offering red horse butter is the best offer: "Nik Akhtar said that the more you send to King Darab, the more and better it will be there. I thought it was the earliest ... Let's send one of those rosy horses that is not in the kingdom for a long time and has not yet been laid on its back ... Then he asked King Fidus and said: You who are a hero, take the rosy ink or take this property and equipment to the service of King Darab ". (Ibid., Vol. 1: p. 10).

Firoozshah becomes attached to him when he sees Ein al-Hayat. Although he had seen this girl as a child, it seems that this time, someone else was in front of him. Beyghami has helped his audience by enumerating the physical features of life draw a detailed picture of a mistress who has caused the Prince of Iran to fall in love with him and his desperate efforts to obtain him. Red has played an important role in these descriptions: "He had two breast pomegranates in his chest, and two jujube rings around his lips, even though he had seen the perfect crescent of life and wore it around his neck as a child," he said. "This Rana is a disaster!"(Ibid., Vol. 1: p. 784)

\section{Yellow}

Yellow is one of the main colors in the psychology of the laser and is somewhat opposite to black. This color has been used in the field of Persian literature mainly to describe the unfavorable physical condition of people. In DarabNameh, we see the contradictory pragmatics of this color. This means that Beyghami has focused on the capabilities of yellow to describe the pros and cons. In total, we see three functions of "description", "description of physical weakness" and "expression of physical beauty" for this color in DarabNameh. The author has stopped using this color on a physiological level and has not mentioned the mental states of the characters in the story. 


\section{Description}

Yellow is the brightest color and appears happily and brightly and indicates relief and expansion of mind.(Luscher, 2010: p. 90)In this respect, it is obvious that we see a special reflection of this color in banquets and celebrations. The festive tools, the type of cover, etc. that are seen in the staging of the stories are often shown in this color. In this way, the author better portrays the hidden and obvious sense of happiness in the scenes for the audience. For example, in the retelling of King Darab's wedding to Gohartaj, Beyghami speaks of the Zarandudi Palace where the ceremony took place. a house where the moon rises from the intensity of light. After joining Darab and Gohartaj, it was time to give birth. The wise Titus appears there with a golden astrolabe to determine the future of the baby through astrology. The author implicitly and on the screen, by mentioning the golden adjective for astrolabe, has narrated the future of the baby (Firoozshah).Yellow is the color of joy, light and light. Therefore, it is clear that Firuz Shah will have a bright and contemplative future. Following the continuation of the narration is a strong reason to confirm this claim: "So they got married and the moon fell from the star to celebrate Homayoun in Zarandood Aflak Palace ... It is said that King Darab arrived and connected that night and he observed Gohartaj until the days of pregnancy approached. "Titus the Wise was ready with a golden astrolabe to determine the omen of the time when he was born."(Beyghami, 1960, vol. 1: p. 8)

Farrokhzad and Firoozshah have set foot in an unknown land where cannibals live. They are arrested and imprisoned for not knowing the area. When they are taken to Shah Zangian, they encounter a magnificent palace. Beyghami provides a beautiful description of the condition of the palace and its inhabitants, and in this regard, has taken advantage of the special capabilities of the color yellow. He describes the king of Zangian with a crown of Mecca, which rests on a throne, and there are several golden chairs on which the courtiers sit, and the Zangians receive them with large golden wine cups. The color yellow has been very effective in representing the glory of this palace: "He has a lavish crown on his head, and he sits on a throne, and he puts about fifty golden chairs, and he sits on every great black man, and a large golden cup full of wine."(Ibid: p. 236).

\section{Description of physical weakness}

Sometimes yellow means despair and evokes feelings of emptiness and isolation and rejection of others.(Luscher, 2010: p. 90)One of the reasons for such conditions can be physical weakness and enduring physiological hardships. Beyghami has mentioned this category many times in DarabNameh. Farrokhzad was injured in the fight against the wicked thief, and the effects of suffering afflicted his body and soul. He was helpless and could not move. Beyghami points out that this condition is one of the consequences of the fifty-day wound that cut Aman Farrokhzad. What has been very effective in making the physical condition of this character tangible is the color yellow; Because Beyghami mentions yellow five times in a short text and its accessories (fire, furnace and gold):"His helpless body was melted in the fire of homelessness and segregation like salt in water and silver in the furnace, and the bamboo mold of his body was yellow in the solitary plant and in the furnace of separation like a golden bowl; "Because Farrokhzad had been wounded for fifty days."(Beyghami, 1960, vol. 1: p. 54) In another part of the story, the narrator describes Firooz Shah's observations of seeing Farrokhzad based on yellow. In the following text, we read that Firoozshah became aware of Farrokhzad's biological and psychological condition after seeing his yellow face, without anyone explaining it to him: "Then they came out of the palace and went to the young man. Firoozshah Nik looked, saw Farrokhzad turn yellow and fainted from fear. He ran forward and lifted his head off the ground and set it aside. Behrooz said to Ayar: O brother! "This is Farrokhzad young man; I do not know how he fell into the hands of this accursed man."(Ibid: p. 232).

Another issue mentioned in yellow is the fear and panic that overwhelms people. The stolen property shudders and trembles when it hears terrible news. His face turns yellow and 
anxiety pervades his being: "The stolen property, when you hear this, turn its color and turn yellow and tremble with zeal."(Ibid., Vol. 2: p. 6).

\section{Expression of physical beauty}

The main characteristics of yellow are: brightness, a reflection of its brilliant quality and its fleeting joy. Physiologically, this color, with the pleasant warmth of the sun, the pleasant halo around the holy wine cup, has a happy mood.(Lusher, 2010: pp. 91-90)On this basis, Beyghami used yellow to describe the charm of the Sun King's face. Shafa al-Molk suddenly sees the Sun King inside the prison. The first thing that catches his attention is the color of Khorshidshah's face, which stays in the yellow sun in yellow. This pleasant aura steals his soul and heart and makes his existence restless and ignites the fire of love in its fabric: "They roamed from roof to roof until they reached the roof of the porch where they were reapers and looked down from the hole. He saw the five of them tied up and sitting on the ground, the Sun King standing like the Sun of Maniz."Shafa 'al-Mulk was restless when he saw the king's sun."(Beyghami, 1960, vol. 1: p. 492)

4. Green

Green color is used in Persian literature to show happiness, joy and vitality. In Luscher psychology, however, there is a completely different view of green from the preconceived notions of green. Luscher believes that those who are very interested in this color have the spiritual qualities of will to do work, perseverance and perseverance.(Luscher, 2010: p. 83)They tend to sit on a chair and introduce themselves as representatives of fundamental and unchangeable principles and have a profound impact on their environment. As a result, they exalt themselves and give moral advice to others.(Ibid: p. 85)The reflection of green in a text, from Luscher's psychological point of view, confirms the positive and negative behavioral characteristics. In the field of Persian literature, especially DarabNameh, this psychological principle has been violated. Although the reflection of green and its accessories in DarabNameh is limited, Beyghami has used it to describe scenes as well as to explain happiness and vitality.

\section{Explain happiness and vitality}

This color is associated with freshness and freshness. "Green has a special place in literature and in the description of nature, and this color is inspired by the leaves of trees and the color of green nature."(Schimmel and Sasuke, 2003: p. 49)This color is soothing and lovely and is used as a symbol of friendship, hope, greenery, growth, health and security, living nature, gardens.(AlShaher, 2002: p. 4)In DarabNameh, the main use of green is to express the favorable physical condition of the characters. This color is used when the characters have survived difficult conditions and have reached peace and quiet by entering a green environment: "Because spring was coming and the world was becoming greener and greener, ein al-Hayat would go to Neshatabad Garden with the midwife and the midwife's daughter, honorable and from the maids."(Beyghami, 1960, vol. 1: p. 40) Firuz Shah was caught in a storm at sea and when he entered an island, he became ill and sick, but eventually escaped from the clutches of death and moved to a valley. There he saw Zaqqum trees with bitter and salty fruits. After a while, he reached a palace where lush gardens with beautiful trees and colorful flowers played. After a long time, he had reached a place where he could take a breath and get rid of the tiredness of traveling: and when he was come into the midst of the valley, he saw the trees of Zaccum, and the bitter fruit, and saw the bitter and salty waters, and went his way. Eventually he saw a palace and set foot in it. When he reached the middle of the porch, he looked around to see the garden door. "He set foot in that garden and fruit trees, flowers, greenery, nasrin and tulips had sprouted."(Ibid., Vol. 2: p. 405)

\section{Description}

The descriptive aspect of green is included in DarabNameh in limited cases. Beyghami describes a rider wearing a green fly on his horse's neck. This description is effective in understanding the 
type of military cover in the past. "He was riding on a dull yoke, and a Chinese mirror apron hung from his compound forehead, and a green rattle hung from the neck of his four-legged friend."(Ibid: p. 41)In another part of the story, Beyghami describes a garden from the perspective of one of the characters: "And he arose, and went into the woods, and saw many fruitful trees, and some withered away, and were cast out at the foot of the trees, and some wet on the branches."Behzad fell and ate and wandered around the island until nightfall."(Ibid: p. 706).

\section{Conclusion}

At DarabNameh, Beyghami uses a variety of tools to nurture and process stories, one of the most important of which is color. He has significantly improved the quality of narratives by exploiting the capacity of black, red, yellow and green colors. The most common colors in DarabNameh are black and red, which is consistent with the content of the work, which is an epic text with a lot of battles. There is a paradox in the use of yellow. Although Beyghami in most cases, has used the same color that we have seen in the field of Persian literature, but in some cases has used yellow to explain the beauty of the characters' faces. In DarabNameh, colors have no symbolic or allegorical aspect. This means that Beyghami has a superficial view of the pragmatics of colors in his work, and his gaze has stopped on the superstructure. The use of blue and its accessories, unlike black and red, has been very limited (less than five times) in DarabNameh, while part of the story is told on the ship and at sea. Also, in this work, when a party is depicted, the author of the ability of colors as they should-Does not uses to make scenes tangible and objective. In this sense, it can be said that Beyghami relied only on the epic aspect of his work. Meanwhile, the writers and poets of other epics have used moral, lyrical, etc. issues in their works to eliminate the monotony of the text, which is a reason for the audience to be bored.In Beyghami DarabNameh, death and war are often mentioned and there is no sign of joy, feasting, etc.By using the right colors, the author could have softened the violent atmosphere of the war and encouraged the audience to follow the story by creating narrative ups and downs. The imbalance in the use of color communication and media capacities is one of the signs of Beyghami's lack of mastery in storytelling and a significant reason for the audience's reluctance to write prose.

\section{References}

Ayatollahi, Habibollah, Basics of color and its application, first edition, Tehran: Samat, 2002.

Beyghami, Haji Mohammad Ibn Sheikh Ahmad, DarabNameh, 2c, with introduction, correction and comments by Dr. Zabihullah Safa, Tehran: Book Translation and Publishing Company, 1960

Jafarpour, Milad and Alavi Moghaddam, Mahyar, "The theme of Ayari and the young man and its educational-inductive teachings in prose epics (Case study: Samak Abar, DarabNameh and Firoozshahnameh)", Textbook of Persian Literature, University of Isfahan, year 5, No. 19, 2013: 13 to 36.

RioFray, Anna Oliver, Children's Painting and Its Concepts, translated by Abdolreza Sarafan and Nemat Nazeri, Tehran: Dastan, 1992.

Sun, Howard and Sun, Dorothy, Life with Color, translated by Saffarian song, first edition, Tehran: Anecdote, 1999.

Alshaher, Abdullah, "The soul effect for us", almoghofoladabi magazine, number 379: 2002: 3 to 27.

Shimel, Anne-Marie and Sask, Persila, "The Values of Color in Iranian Art and Literature", translated by Maryam Mirahmadi, Letter of the Association, No. 12, 2003: 40-58.

Sarfi, Mohammad Reza and Rahimi Sadegh, Khadijeh, "A Study of the Narrative Type of Beyghami DarabNameh", Yazd University Research, Volume 17, Number 32, 2016: 139165.

Farzan, Nasser, Color and Nature, Part of the Knowledge of Colors, Tehran: Tehran, 1996. 
Filmar, Klaus brand, colors and their healing nature, translated by Shahnaz Azarniush, Tehran: Phoenix, 1992

losher, Max, Psychology of Colors, translated by Vida Abizadeh, twenty-seventh edition, Tehran: Dorsa, 2010. 